\title{
Tell me your age and I tell you what you trust: the moderating effect of generations
}

\begin{abstract}
Purpose

The proliferation of social commerce websites has allowed consumers to share and exchange information, experiences, advice and opinions. Recently, information provided by users has been considered more trustworthy than the information shared by companies. However, the way in which users interact with technology can vary with age, and generational cohorts show different shopping behaviors, interests and attitudes. Hence, the way users process information (user-generated vs. company-generated) can affect trust differently. Drawing on trust transfer theory and generational cohort theory, this study analyzes the effects on user- and company-generated information in boosting trust of three different cohorts (Generations X, Y and Z).
\end{abstract}

\section{Design/methodology/approach}

The data were collected through an online survey. The sample comprised 715 users of social commerce websites, aged between 16 and 55 years old. The study was analyzed using partial least squares with the statistical software Smart PLS 3.

\section{Findings}

The empirical results show that generational cohorts show different patterns. Generation $X$ transfers trust to social commerce websites mainly from trust in information generated by companies, while Generation $\mathrm{Z}$ transfers trust mainly from information generated by users. Finally, Generation Y, in contrast to previous findings about millennials, develops trust based on company-generated information to an even greater extent than does Generation X.

\section{Originality}

The originality of this study lies in its analysis of generational differences when it comes to trusting one type of information over another. This study contributes to the idea that users cannot be considered as a whole but must be segmented into generational cohorts.

Keywords: Generation X, Generation Y, Generation Z, trust transfer theory, generational cohort theory, social commerce 


\section{Introduction}

Social commerce has gained increasing attention in recent years (Zhang and Benyoucef, 2016). Social commerce websites are platforms that aim to facilitate the sharing and exchange of information among users (Zhang et al., 2014) and are defined as a combination of e-commerce, social networks and social media (Lu et al., 2016; Liang and Turban, 2011). Using social commerce platforms, users can buy products, share information, exchange opinions, receive advice from trustworthy individuals (Ickler et al., 2009; Kim et al., 2012; Zhou et al., 2013) and even make group purchases (Kim, 2013). This kind of trade is based on B2C and C2B2C interactions, enabling users to play an active role in the website based on the opportunity to generate information and influence other users' purchase decisions (Prahalad and Ramaswamy, 2004). Forrester (2016) reported that online consumers rely on online information to make daily choices, and $42 \%$ of interviewees affirmed that they read detailed product reviews at least weekly. According to PricewaterhouseCoopers (2016), 78\% of online users stated that they are influenced by social media and $45 \%$ of consumers were influenced by reading reviews, comments and feedback.

The purchase experience in social commerce differs from that of traditional e-commerce, primarily based on the participation aspect, since users can get involved in the generation and sharing of content (Huang and Benyoucef, 2013). Social commerce generates utilitarian, hedonic and social value for users affecting purchase intention (Gan and Wang, 2017). Social commerce platforms, in addition to the information generated by companies, contain tools that facilitate participation and interaction among users, companies and the community. Among the tools offered by social commerce websites that allow the exchange of information are systems for recommendations, referrals, ratings, references, virtual communities, discussion forums, wish lists, social networks, etc. Hence, users are seen as content consumers and content producers (Constantinides, 2014). Consequently, consumers take part in the co-creation of value (Jiao et al., 2015), which increases their purchase and participation intention (Blasco-Arcas et al., 2014). Therefore, in the purchase decision process, when it comes to trusting social commerce websites based on the information available, users can refer not only to that provided by the company, but also that generated and shared by other users. On social commerce websites, the reliability of the information depends not only on the content provided by the company, but also on user-generated content.

It is believed that people are more likely to trust information that is shared by other consumers than that shared by companies (Dabholkar and Sheng, 2012; Smith et al., 2005; Dellarocas et al., 2007). However, the question arises as to whether we can generalize this to all Internet users, or whether the different generations behave differently from one another. Some studies have already shown that age can affect users' behavior, since technology inclusion is not equal for all generations and moreover, consumers' interests and attitudes vary with age (San-Martín et al., 2015). Likewise, different generational cohorts show different preferences and shopping behaviors on the Internet (Bilgihan, 2016; Parment, 2011; Parment, 2013).

Research about the differences among generations when shopping online is scarce. Several studies have focused on analyzing how one specific generation behaves online, but no studies have compared how different generational cohorts behave on social commerce websites and how they develop trust regarding the source of information with which they interact. Hence, it is considered interesting here to study whether there are generational differences in users' interaction with the different kinds of online information. Therefore, drawing on trust transfer theory (Stewart, 2003; $\mathrm{Ng}, 2013$ ) and generational cohort theory (Inglehart, 1977), the aim of this study is to contribute to research into online information, by analyzing whether generational differences exist when it comes to trusting one type of information over another (trust in user- vs. company-generated information). To do so, this study proceeds along two steps; first, an integrated model is proposed to analyze the importance of trust in user- vs. company-generated information in boosting trust in social commerce 
websites; second, the moderating role of age is studied through a consideration of Generations X, Y and $\mathrm{Z}$ in social commerce contexts.

The following section reviews the literature on the two kinds of online information (trust in uservs. company-generated) and its role in social commerce is contextualized through trust transfer theory and generational cohort theory. Next, the moderating roles of generational cohorts $\mathrm{X}, \mathrm{Y}$ and $\mathrm{Z}$ are presented, followed by definition of the hypotheses. Generation $\mathrm{X}$ refers to people born between 1960 and 1980; that is, currently between 35 and 55 years old. Generation Y refers to people born between 1981 and 1990; now around 25 and 34 years old. Generation $\mathrm{Z}$ refers to the youngest population, born between 1991 and 2000, now younger than 24 years old. Although this categorization is still under debate, as shown in section 3, based on several reports the three generational cohorts can be classified depending on the inclusion of each cohort into the online environment, that it, based on the period of time when people were born and the Internet development. Section 4 describes the methodology and the data analyzed; section 5 presents the results; and the paper concludes with the theoretical and business implications and limitations of the work and lines of future research.

\section{Literature review}

\subsection{Trust}

Trust has been widely studied in online commerce environments (Gefen and Straub, 2003; GrabnerKräuter and Kaluscha, 2003, Ng, 2013; Sharma and Crossler, 2014; Farivar et al., 2017). According to Gefen and Straub (2003), trust is defined as users' necessity to control the social environment in which they live and interact. In social commerce, trust has been defined as the willingness of scommerce users to trust in the ability, generosity, integrity, and predictableness of a seller based on the belief that the seller would take certain action crucial for its customers regardless of their capability to monitor or control the seller (Kim and Park, 2013, p. 325). Therefore, the information contained on a website could contribute to trust, although this information is not only generated by the seller, but also by other users. In online environments, trust is crucial to mitigate the risk and insecurity barrier. Grabner-Kräuter and Kaluscha (2003) reviewed literature about trust in the ecommerce context and stated that there is a common belief that trust only exists in an uncertain and risky environment. According to the authors, an uncertain environment is one in which there is a lack of control and the available resources are limited. Hence, through online content, companies can offer more sources of information and users can make use of social tools to share and obtain information, while also controlling the information exchanged. Trust toward the social commerce site not only reduces perceived risk, but also increases purchase intentions (Farivar et al., 2017). Within social commerce, social interactions can change the perception of uncertainty and insecurity; this is due to factors of sociability and human contact, which can encourage positive attitudes towards Internet shopping (Hassanein and Head, 2007). If social commerce users trust a website, it is assumed that this trust will be reflected in the comments and the information shared on the platform, whereby trust can be transferred from one user to another.

Trust transfer theory postulates that trust can be transferred from different sources, such as individuals, the communication process, or the context (Stewart, 2003; Ng, 2013). The development of trust is based on a cognitive process, among other things, since users not only process the information but also derive an impression about the source (Stewart, 2003). It has been suggested that one of the necessary conditions for trust transfer is the existence of perceived relational bond (Wu et al., 2016). Hence, this study considers that transfer of trust from user- or company-generated information to social commerce websites might depend on the generational cohort, since age groups share unique common bonds. Trust transfer in online settings has also been studied by several authors; for instance, Pavlou and Gefen (2004), in a study on how to build trust in online auction 
marketplaces, found that trust in an intermediary can be transferred to trust in the community of sellers. Trust can be also transferred from online payment to mobile payment continuance intention through satisfaction (Cao et al., 2018). In the social commerce context, Shi and Chow (2015) suggested that trust is not only based on the trustworthiness of companies, but also on social interactions, naming information-based trust as trust in information from companies and from other customers in social commerce, where trustworthy information is understood as that which is accurate, valid and reliable. According to these authors, on social commerce websites "trust is important for customers to evaluate the quality of information from various sources, and serves as a foundation for their sharing of information with others" (Shi and Chow, 2015, p. 1183). Also in social commerce, it has been shown that trust toward members can be transferred into trust toward the community (Chen and Shen, 2015), and that users may develop trust based on information from the social community (Ng, 2013). Therefore, drawing on trust transfer theory, this study hypothesizes that trust can be transferred as much from user to user as from company to user. The current investigation considers two kinds of information sources (though there are other variables that obviously also generate trust). On the one hand, in social commerce contexts, trust is increased by social WOM - that is, the information shared by users. Indeed, several authors have stated that user-generated information has a positive effect on trust (Filieri, 2015; Han, 2014; Kuan and Bock; 2007, Bock et al., 2012). On the other, users can develop trust based on website content provided by the company (Chen et al., 2015; Beldad et al., 2010; Kim and Park, 2013). Thus, focusing on these

two sources of information, this study considers how Generations $\mathrm{X}, \mathrm{Y}$ and $\mathrm{Z}$ differ in terms of trusting information sources (trust in user- vs. company-generated information).

\subsection{User-generated information}

User-generated information refers to content posted and shared by users on social commerce websites. In this study, trust in user-generated information refers to trustworthy, frank and reliable user-generated content shared by recommendations and referrals, ratings and reviews, and forums and virtual communities (Hajli et al., 2014). These tools offer an important amount of information and help others to make informed purchase decisions (Liu et al., 2011). Participation is crucial to boost information quality on websites (Yang et al., 2015) and it has been shown that information provided via social commerce has a positive effect on trust (Han, 2014; Jung, 2014). Likewise, social commerce components - again including recommendations and referrals, forums and virtual communities, and ratings and reviews - increase trust, whilst decreasing mistrust (Hajli, 2015). The quality of information shared by other users via websites refers to its relevance, accuracy, credibility and usefulness, among other aspects (Filieri, 2015). As a rule of thumb, social commerce websites are seen as trustworthy platforms because the information is generated by consumers themselves (Linda, 2010). It has been shown that online peer recommendations influence trust in social media settings (See-To and Ho, 2014) and the quality of the information, communication and WOM is critical in building this trust (Linda, 2010). According to Alshibly (2014), the effectiveness of social commerce depends, among other things, on the system and the information, which must be detailed, comprehensible and up to date. In fact, the success of a website consists of shared information and fostering connectivity and socialization (Hodis et al., 2015).

\subsection{Company-generated information}

Company-generated information pertains to product-related content offered by the company on the website, with the intention of providing details such as product descriptions, sizes, measurements, available options, images and videos, materials, prices, delivery information, etc. In other words, all the information created and spread by the company. Company-generated information refers to the latest, accurate, and complete information provided by a website to its users (Kim and Park, 2013). According to Lin and Lu (2000), the quality of the website depends on the information provided and the site's responsiveness and accessibility. Hernández-Ortega et al. (2009) stated that the 
quality of a website is measured partly in terms of accessibility and content. This is why various investigations have highlighted the importance of companies focusing on the reliability of the content they offer. The information itself can also positively affect trust (Chen et al., 2015; Beldad et al., 2010; Kim and Park, 2013) and it has been said that the information offered by the company decreases the perception of uncertainty and risk in electronic commerce and thus has a positive effect on trust (Kim et al., 2008; Liao et al., 2006).

Figure 1. Conceptual model of trust transfer in social commerce contexts

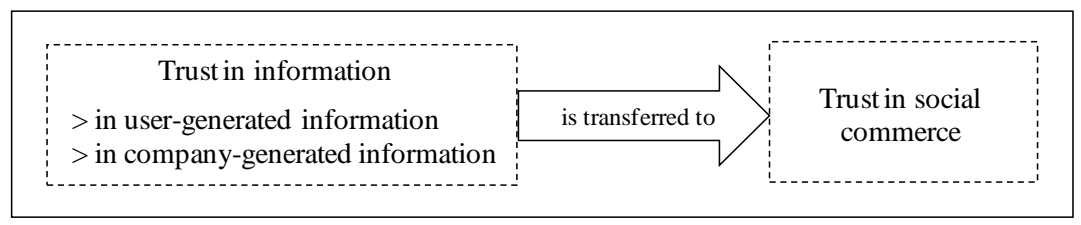

\subsection{Generational cohort theory}

However, marketers should not approach users as a whole, since age can affect consumers' interest, attitudes and shopping behaviors (Meriac et al., 2010; San-Martín et al., 2015; Parment, 2011; Parment, 2013; Pieri and Diamantinir, 2010). Hence, segmenting the target would improve companies' ability to focus on the information source that must be stressed in order to foster trust on the social commerce website. Generational cohort theory (Inglehart, 1977) posits that populations can be segmented into generational cohorts based on their years of birth, since age groups develop common attitudes and beliefs based on their life experiences (Meriac et al., 2010; Meredith and Schewe, 1994; Howe and Strauss, 1992). Hence, generation market segmentation has been considered more efficient that segmenting simply by age (Lissitsa and Kol, 2016; Schewe et al., 2000; Parment, 2013), without considering group attitudes and behavior. Generational cohort theory has been applied to studying offline (Brosdahl and Carpenter, 2011; Jackson et al., 2011; Pentecost and Andrews, 2010) and online consumer behavior (Bilgihan, 2016; Lissitsa and Kol, 2016). However, to the best of our knowledge, it has not been studied in social commerce contexts to date.

\section{Development of hypotheses and research model}

Several studies have already shown the importance of online information on trust (Filieri, 2015; Han, 2014; Chen et al., 2015); however, the vast majority has tested the influence of each type of information together with other antecedents of trust. The conceptual model proposed in this study is based on the idea that trust can be transferred from the information generated-whether by users or by the company - to the social commerce website. That is, if users trust in user- or companygenerated information, this trust will be transferred to the social commerce website (see Figure 1). Based on trust transfer theory, the research model proposed in this paper relies on comparative analysis in order to study the individual influence of each source of information on trust. The main contribution of this investigation is provided in the following lines, in which the moderating effect of generational cohorts is hypothesized in order to study the effect on different types of information of different generations.

Generational cohorts have been segmented to show the development of similar attitudes and beliefs among people (Meriac et al., 2010). We can distinguish three main generational cohorts currently: Generation X, or X-ers (between 1960 and 1980); Generation Y, Y-ers, or millennials (between 1981 and 1990); and Generation Z, Z-ers, post-millennials, or centennials (between 1991 and 2000). Generation X grew up before the Internet was launched, but X-ers have learnt to deal with online environments (American Marketing Association, 2016b). X-ers find explanations of product features necessary to make purchase decisions (Himmel, 2008); read reviews and opinions; and 
look for convenience and community relations (Lissitsa and Kol, 2016). Generation Y grew up with technology (Palmer, 2009) and is used to a wide range of online activities (Bilgihan et al., 2013, Lester et al., 2006). It is said that Generation Y processes website information five times faster than older generations do (Kim and Ammeter, 2008). Y-ers are also known as digital natives, the millennial generation or the next generation (Bilgihan, 2016). Members of Generation $\mathrm{Z}$ were born during the 1990s (American Marketing Association, 2016a), have not lived in a world without the Internet and are on social networks such as Facebook, Instagram and Snapchat (Puro Marketing, 2015). Z-ers were born in a post-linear digital world and have been described as industrious and collaborative users (Kantar Millward Brown, 2016).

This study considers the moderating role of age, specifically through the three different cohorts: Generations X, Y and Z. Several authors have argued that young users are more experienced with the Internet (e.g. San-Martín et al., 2015) because, in the case of millennials, they grew up with this technology (Palmer, 2009). However, although young people are more used to the Internet (Pieri and Diamantinir, 2010), older users are more experienced in terms of purchasing (Alam et al., 2008). The moderating role of age has been studied in e-commerce (Yoon, 2002, Kim et al., 2012, Hill and Beatty, 2011) and m-commerce (San-Martín et al., 2015) contexts to observe differences in the behavior of adults compared to young adults. Although Yoon and Occeña (2015) studied age as a moderator of trust in e-commerce, to the best of the current authors' knowledge, it has not been tested before in social commerce contexts. Hence, if trust depends on the information provided, it can be said that the different kinds of information users process (user- vs. company-generated) can affect trust in social commerce differently as well. Based on the idea that X-ers require product explanations to make their purchase decisions, we can consider that the oldest generation will trust more on the company-generated information than user-generated information.

In relation to the above, it can be considered that the younger the generation, the more willing people will be toward user-generated content. The importance of user-generated information is that individuals produce and consume it (Ickler et al., 2009) and can get opinions from a community, thereby accessing up-to-date content in a common jargon (Grange and Benbasat, 2010), feeding the system and offering more information. This information generated on social commerce websites increases trust (Hajli et al., 2014). It has been shown that information provided by users on websites positively affects trust (Filieri, 2015; Han, 2014; Kuan and Bock, 2007; Bock et al., 2012). Because Z-ers and Y-ers seem to be most active on the Internet, since they are used to online environments, it is assumed that they will tend more toward user-generated information. This begs the following research questions: RQ1: Is it true that the younger the generation, the more trust in social commerce is transferred from trust in user-generated information?; and RQ2: Is it true that the older the generation, the more trust in social commerce is transferred from trust in companygenerated information? Thus, based on these questions, we hypothesize the following moderating effects of generational cohorts (see the research model in Figure 2):

$\boldsymbol{H} . \boldsymbol{X}$-ers: For X-ers, trust in social commerce is transferred mainly from trust in companygenerated information than from trust in user-generated information.

H.Y-ers: For Y-ers, trust in social commerce is transferred mainly from trust in usergenerated information than from trust in company-generated information.

H.Z-ers: For Z-ers, trust in social commerce is transferred mainly from trust in usergenerated information than from trust in company-generated information.

Figure 2. Research model 


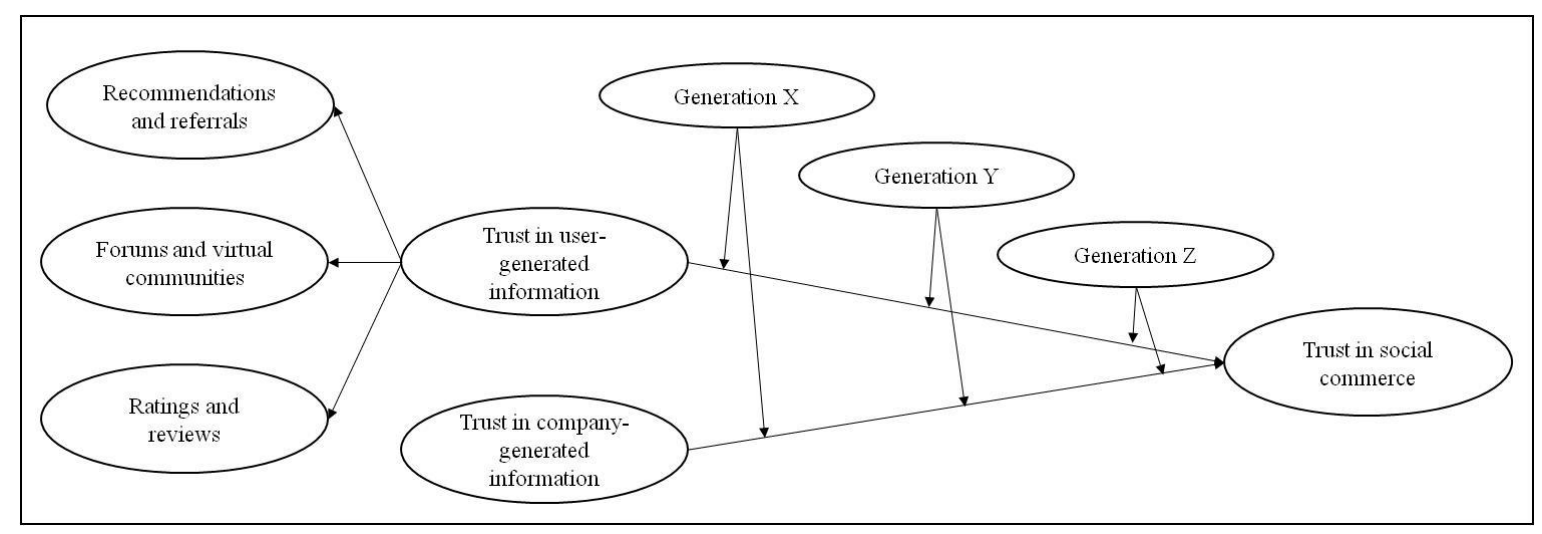

\section{Methodology and data analysis}

\subsection{Survey, sample and data-collection procedure}

The data used for this analysis were collected between February and June 2015 through an online survey carried out by a specialized market research agency. The respondents' age range was representative of the Spanish online consumer population according to Telecommunication and Information Society Spanish Watch (ONTSI, 2014). The total number of responses was 771, but participants older than 55 years were removed from the sample, since they do not belong to the generations studied in this investigation. Likewise, after having collected all the data and reviewed the literature about generations, the sample was segmented into the three generational cohorts studied in this investigation, based on the years of birth of the respondents. In this way, the distribution of data was ensured to represent Spanish online consumer society. The final sample consisted of 715 users of social commerce websites, of which $49.9 \%$ were male and $50.1 \%$ female, with ages ranging from 16 to 55 (see Table 1). All respondents were online buyers who had recently bought from social commerce websites.

At the beginning of the questionnaire, after being informed about the anonymity of the questionnaire and the lack of right or wrong responses and being given an explanation of the concept of social commerce, the participants were asked whether they had recently purchased using a website with the characteristics of a social commerce platform. If they answered yes, they carried on answering the survey and were asked to name the social commerce website from which they had purchased. Among their answers were Amazon (34\%), AliExpress (7\%) and Booking (3.5\%). Throughout the questionnaire, the respondents were continuously asked to recall their experience on the website they had chosen.

Table 1. Detailed demographics of the participants

\begin{tabular}{|c|c|c|c|}
\hline Age & \multicolumn{2}{|c|}{ Data collected } & Gender (Female/Male) \\
\hline Z-ers: $16-24$ & 135 & $19 \%$ & $58 \% / 42 \%$ \\
\hline Y-ers: $25-34$ & 262 & $37 \%$ & $46 \% / 54 \%$ \\
\hline X-ers: $35-55$ & 318 & $44 \%$ & $50 \% / 50 \%$ \\
\hline Total & 715 & $100 \%$ & $50.1 \% / 49.9 \%$ \\
\hline
\end{tabular}

\subsection{Instrument development and validation}

Before commencing data collection, the survey instrument was checked by various experts in order to ensure that all items and text were understandable and thereby to assess face and content validity. 
This pretest led to some minor changes, most of which were oriented toward shortening the questionnaire's length and making it easier to complete.

In order to ensure content validity, literature about the variables included in the model was thoroughly reviewed and the variables were adapted to the social commerce context. The survey was checked by several experts. Trust in user-generated information was measured as a secondorder reflective construct that consists of three sub-dimensions-the information derived from recommendations and referrals; forums and virtual communities; and ratings and reviews - with three items in each, adapted from the scales of Han and Windsor (2011) and Hajli et al. (2014). Trust in company-generated information consisted of three items adapted from the scale of information quality by Kim and Park (2013). Trust in social commerce, which comprised four items, was adapted from the scale of Kim and Park (2013) (see Table 2). All survey variables were measured on a seven-point Likert scale, with the lowest score being 1 (strongly disagree) and the highest 7 (strongly agree). Age was measured using a nominal scale and gender was gauged using a non-ratio scale in order to collect the exact age and thus build up the generational cohort segments.

Table 2. Scale

\begin{tabular}{|ll|}
\hline \multicolumn{1}{|c|}{ Scale } \\
\hline Trust in & user-generated information-adapted from the scale of Han and Windsor (2011), Hajli et al. $(2014):$ \\
RR1 & Overall, the recommendations and referrals on this social commerce website are trustworthy. \\
RR2 & I feel the recommendations and referrals on this social commerce website are generally frank. \\
RR3 & I feel the recommendations and referrals on this social commerce website are generally reliable. \\
FC1 & Overall, the forums and communities on this social commerce website are trustworthy. \\
FC2 & I feel the information from forums and communities on this social commerce website is generally frank. \\
FC3 & I feel the information from forums and communities on this social commerce website is reliable. \\
RRw1 & Overall, the ratings and reviews on this social commerce website are trustworthy. \\
RRw2 & I feel the ratings and reviews on this social commerce website are generally frank. \\
RRw3 & I feel the ratings and reviews on this social commerce website are reliable. \\
\hline Trust in company-generated information-adapted from the scale of Kim and Park (2013): \\
CI1 & This social commerce website provides accurate information on the item that I want to purchase. \\
CI2 & This social commerce website provides reliable information. \\
CI3 & This social commerce website provides sufficient information when I try to make a transaction. \\
\hline Trust in social commerce-adapted from the scale of Kim and Park (2013): \\
T1 & This social commerce website is trustworthy. \\
T2 & This social commerce website wants to be known as a company that keeps its promises and commitments. \\
T3 & This social commerce website will keep its promises. \\
T4 & I believe in the information that this social commerce website provides. \\
\hline
\end{tabular}

Note: $\mathrm{RR}=$ Recommendations and referrals; $\mathrm{FC}=$ Forums and virtual communities; $\mathrm{RRw}=$ Ratings and reviews; $\mathrm{CI}=$ Trust in companygenerated information; $\mathrm{T}=$ Trust in social commerce.

\subsection{Multivariate assumption of normality}

The multivariate assumption of normality was tested through the asymmetry and kurtosis valueswhich were greater than 2.52 and 1.96, respectively (Hair et al., 2010) - and the significance of the Kolmogorov-Smirnov-Lilliefors and Shapiro-Wilk statistics, so that distribution of the data did not fulfill the hypothesis of normality.

\subsection{Exploratory factor analysis}

Before validating the full measurement and structural model, an exploratory factor analysis was conducted using the principal axis factoring method and varimax rotation (Hair et al., 1999; Kaiser, 1970; Kaiser, 1974) with SPSS 22. The Kaiser-Meyer-Olkin (KMO) value was greater than the threshold of 0.70 (KMO trust in user-generated information $=0.906$; $\mathrm{KMO}$ trust in company- 
generated information $=0.743$; KMO trust in social commerce $=0.849$ ) and Barlett's sphericity test was significant. The findings show that each item loaded onto its factor.

\subsection{Measurement model validation}

The focus of data analysis is the effect on different types of information (trust in user- vs. companygenerated information) of different generations (Generations $\mathrm{X}, \mathrm{Y}$ and $\mathrm{Z}$ ) in boosting trust toward the social commerce website. To do so, firstly, we ran the measurement and the structural model in order to test the relationship between trust in user- and trust in company-generated information on trust in social commerce; and secondly, we analyzed the moderating effects of generational cohorts.

\subsubsection{Convergent validity and construct reliability}

To ensure the validity and reliability of the measurement scale, construct validity was analyzed using partial least squares (PLS) with the statistical software Smart PLS 3 (Ringle et al., 2015). Construct validity determines whether there are high correlations between measures of the same construct-i.e., convergent validity - and low correlations between measures of constructs that are expected to differ-i.e., discriminant validity (Straub, 1989; Campbell and Fiske, 1959).

Based on Fornell and Larcker (1981), to assess convergent validity the reliability of each item was examined and deemed to show internal consistency when the Cronbach's alpha (CA) values were higher than 0.70 (Nunnally and Bernstein, 1994; Nunnally, 1978). The composite reliability (CR) of each construct was also considered, with values greater than 0.60 deemed acceptable (Bagozzi and Yi, 1988; Fornell and Larcker, 1981), along with the average variance extracted (AVE), which had to exceed the value of 0.50 (Fornell and Larcker, 1981) and advisable be greater than 0.70 (Hair et al., 2014).

Table 3. Reliability and convergent validity of the measurement model

\begin{tabular}{|c|c|c|c|c|c|c|c|c|}
\hline Variable & Item & Mean & SD & Loading & t-value & $\overline{C A}$ & CR & AVE \\
\hline $\begin{array}{l}\text { Trust in user- } \\
\text { generated } \\
\text { information }\end{array}$ & $\begin{array}{l}\text { RR1 } \\
\text { RR2 } \\
\text { RR3 } \\
\text { FC1 } \\
\text { FC2 } \\
\text { FC3 } \\
\text { RRw1 } \\
\text { RRw2 } \\
\text { RRw3 }\end{array}$ & $\begin{array}{l}5.37 \\
5.32 \\
5.32 \\
5.27 \\
5.23 \\
5.19 \\
5.40 \\
5.33 \\
5.30\end{array}$ & $\begin{array}{l}1.229 \\
1.258 \\
1.226 \\
1.309 \\
1.314 \\
1.281 \\
1.261 \\
1.282 \\
1.282\end{array}$ & $\begin{array}{l}0.867 \\
0.887 \\
0.889 \\
0.857 \\
0.857 \\
0.884 \\
0.870 \\
0.875 \\
0.882\end{array}$ & $\begin{array}{l}62.364 * * * \\
70.926 * * * \\
87.189 * * * \\
59.405 * * * \\
51.545 * * * \\
80.553 * * * \\
87.189 * * * \\
70.569 * * * \\
73.397 \text { *** }\end{array}$ & 0.961 & 0.967 & 0.764 \\
\hline $\begin{array}{c}\text { Trust in company- } \\
\text { generated } \\
\text { information }\end{array}$ & $\begin{array}{l}\text { CI1 } \\
\text { CI2 } \\
\text { CI3 }\end{array}$ & $\begin{array}{l}5.29 \\
5.23 \\
5.25\end{array}$ & $\begin{array}{l}1.231 \\
1.243 \\
1.235\end{array}$ & $\begin{array}{l}0.883 \\
0.923 \\
0.898\end{array}$ & $\begin{array}{r}75.199 * * * \\
138.940 * * * \\
87.094 * * *\end{array}$ & 0.885 & 0.928 & 0.812 \\
\hline $\begin{array}{l}\text { Trust in social } \\
\text { commerce }\end{array}$ & $\begin{array}{l}\text { T1 } \\
\text { T2 } \\
\text { T3 } \\
\text { T4 }\end{array}$ & $\begin{array}{l}5.53 \\
5.56 \\
5.44 \\
5.35\end{array}$ & $\begin{array}{l}1.266 \\
1.288 \\
1.278 \\
1.279\end{array}$ & $\begin{array}{l}0.918 \\
0.894 \\
0.941 \\
0.914\end{array}$ & $\begin{array}{r}118.540 * * * \\
58.177 * * * \\
163.592 * * * \\
100.472 * * *\end{array}$ & 0.937 & 0.955 & 0.841 \\
\hline
\end{tabular}
0.01 .

\subsubsection{Discriminant validity}

The discriminant validity was tested to confirm that the constructs differed from each other. To do so, first, the cross-loadings (Hair et al., 1999) were analyzed. Second, a symmetric matrix was used 
to corroborate that the AVE on the diagonal was larger than its corresponding squared correlation coefficients in its rows and columns (Fornell and Larcker, 1981; Hair et al., 1999). Finally, the HT/MT (Heterotrait/Monotrait) ratio between correlations (Henseler et al., 2015) was determined; this showed discriminant validity when the correlations between the construct items were higher than the correlations that measured other constructs. The measurement model results are shown in Tables 3 and 4.

Table 4. Discriminant validity

\begin{tabular}{|l|c|c|c|}
\hline & $\begin{array}{c}\text { Trust in user- } \\
\text { generated } \\
\text { information }\end{array}$ & $\begin{array}{c}\text { Trust in company- } \\
\text { generated } \\
\text { information }\end{array}$ & $\begin{array}{c}\text { Trust in } \\
\text { social } \\
\text { commerce }\end{array}$ \\
\hline Trust in user-generated information & $\mathbf{0 . 8 7 4}$ & 0.557 & 0.534 \\
\hline Trust in company-generated information & 0.600 & $\mathbf{0 . 9 0 1}$ & 0.647 \\
\hline Trust in social commerce & 0.508 & 0.595 & $\mathbf{0 . 9 1 7}$ \\
\hline
\end{tabular}

Note: Diagonal values are AVE squared roots. Below the diagonal: correlations among factors. Above the diagonal: the HT/MT ratio

\section{Results}

\subsection{Testing of the hypotheses and full structural model}

The validity of the model was assessed by analyzing the structural path coefficients and the percentage of variance explained, since PLS does not generate an overall goodness-of-fit index as does structural equation modeling. Bootstrapping was performed with 5,000 sub-samples to test the statistical significance. The empirical results (shown in Table 5 and Figure 3) confirm that the relationships of the parsimonious model are supported. Specifically, the findings show that trust in user-generated information $(\beta=0.257, \mathrm{t}=4.997, \mathrm{p}<0.01)$ and trust in company-generated information $(\beta=0.452, t=9.087, \mathrm{p}<0.01)$ positively influence trust on social commerce websites. It is noteworthy that the effect of trust in company-generated information on trust in social commerce was greater than the effect of trust in user-generated information. The analyses explained $39.80 \%$ of the variance of trust in social commerce. A blindfolding analysis, through crossvalidated redundancy (Hair et al., 2014), confirmed that the model has predictive relevance.

Table 5. Structural model results

\begin{tabular}{|l|c|c|}
\hline Paths & $\begin{array}{l}\text { Standardized } \\
\text { coefficients }(B)\end{array}$ & $\begin{array}{l}\text { T-Value (t) } \\
\text { (bootstrapping) }\end{array}$ \\
\hline Trust in user-generated information $\rightarrow$ Trust in social commerce & 0.257 & $4.997 * * *$ \\
\hline $\begin{array}{l}\text { Trust in company-generated information } \rightarrow \text { Trust in social } \\
\text { commerce }\end{array}$ & 0.452 & $9.087 * * *$ \\
\hline $\begin{array}{l}\text { Variance explained of trust in social commerce: } \mathrm{R}^{2}=0.398 \\
\text { Blindfolding analysis: } \mathrm{Q}^{2} \text { (Trust in social commerce) }=0.333\end{array}$ \\
\hline
\end{tabular}

Figure 3. Structural model 


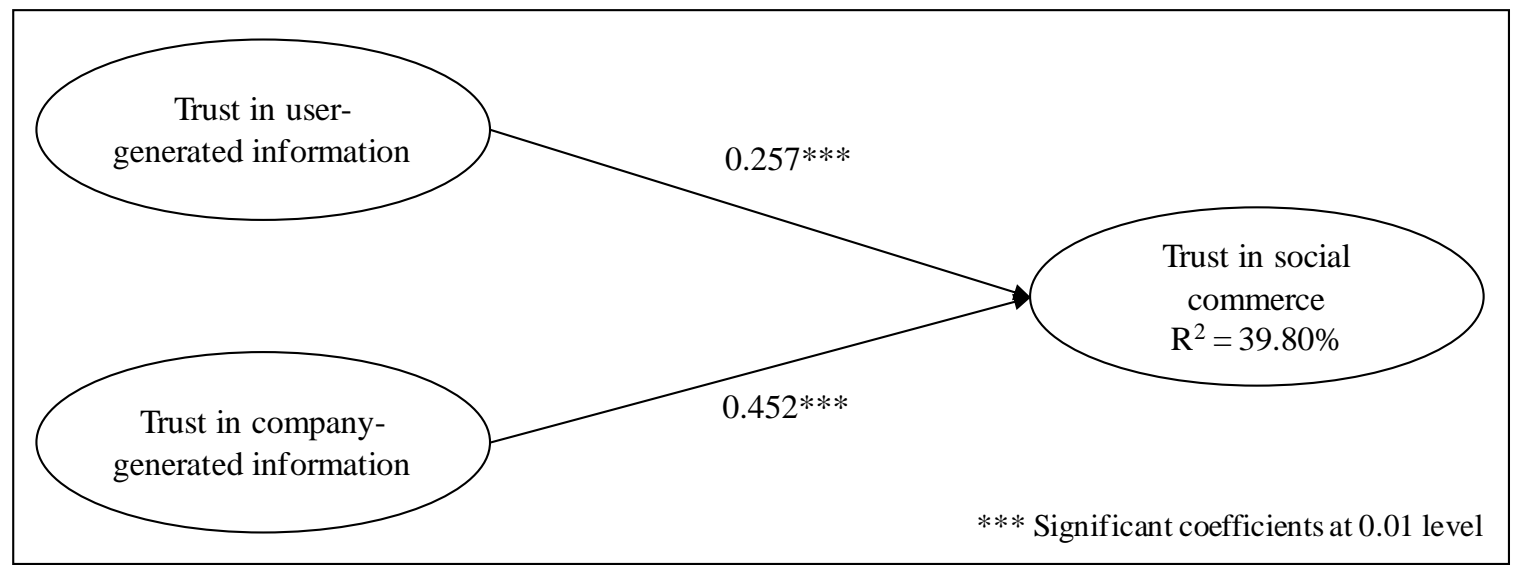

The empirical results show that trust in company-generated information is more important in boosting trust in social commerce than trust in user-generated information is. Next, the study examined the different generational cohorts' development of trust, through the moderating effects of age according to Generations $\mathrm{X}, \mathrm{Y}$ and $\mathrm{Z}$.

\subsection{Moderating effects}

A moderator variable is defined as one that systematically modifies the direction or strength of the relationship between an exogenous and an endogenous variable (Sharma et al., 1981; Baron and Kenny, 1986). To analyze the following moderating effects, multi-group analyses were conducted to test the difference between means using t-tests. Furthermore, through the parametric approach, the significance of the parametric test was observed (Chin, 2000; Sánchez-Franco and Roldán, 2005) and the Welch-Satterhwaite test (Keil et al., 2000); and through the non-parametric approach the significance of Henseler's Multigroup Analysis Test was determined (Henseler et al., 2009).

According to the analysis of the effect on different types of trust in information (user- vs. companygenerated information) of different generations (Generations $\mathrm{X}, \mathrm{Y}$ and $\mathrm{Z}$ ) in boosting trust in social commerce websites, there is support for the hypotheses H.X-ers and H.Z-ers, since X-ers do not transfer their trust in social commerce mainly from trust in user-generated information, but rather from trust in company-generated information (H.X-ers); and Z-ers transfer their trust in social commerce mainly from trust in user-generated information, rather than from trust in companygenerated information (H.Z-ers). However, contrary to expectations, Y-ers' trust in social commerce is transferred mainly from trust in company-generated information, rather than from trust in user-generated information; thus, hypothesis H.Y-ers is not supported.

Table 6 shows the variations in the path coefficients for each of Generations X, Y and Z, for each of the proposed hypotheses. The results indicate potential differences between the three subsamples (Generations X, Y and Z). First, Generation X showed a similar pattern to the original structural model (Busers $=0.257<$ Bcomp $=0.452$ ); for X-ers, trust in company-generated information $(\mathrm{H} . \mathrm{X}$ ers: ßcomp $=0.392$ ) is more important in the development of trust in social commerce than trust in user-generated information is (H.X-ers: Busers $=0.275)$, although this difference is even greater for Generation Y (H.Y-ers: Busers $=0.167<\beta c o m p=0.565)$. However, the difference between the two subsamples (Generation $\mathrm{X}$ vs. $\mathrm{Y}$ ) is not significant in the case of trust in user-generated information. Second, when comparing between Generations X and Z, Z-ers show opposite results compared to X-ers (H.Z-ers: Busers $=0.492<$ <comp $=0.298$ ); for Z-ers, trust in user-generated information is more important in boosting trust in social commerce than trust in company-generated information is. Third, by comparing between Generations $\mathrm{Y}$ and Z, differences in subsamples were detected. In response to the research questions, we can conclude that the younger the generation, the 
more trust in social commerce is transferred from trust in user-generated information. However, Generation Y's trust in social commerce is transferred from trust in company-generated information to a greater extent than for the older generation - that is, Generation X.

Table 6. Structural model results for the three subsamples

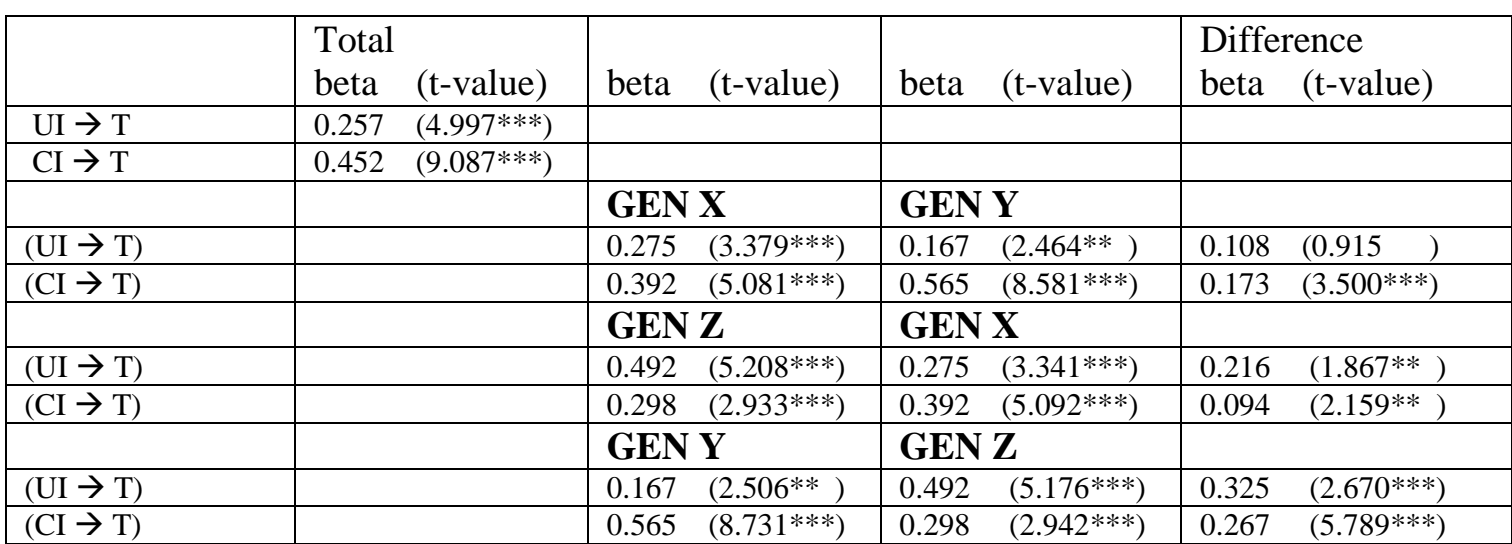

When the $t$ value obtained using the bootstrap method is greater than Student's t value, the hypothesis is confirmed with a significance of 99\%. $* * * \mathrm{p}<0.01(\mathrm{t}=2.6012)$. $* * \mathrm{p}<0.05(\mathrm{t}=1.9722)$. UI $=$ Trust in user-generated information; $\mathrm{CI}=$ Trust in company-generated information; $\mathrm{T}=$ Trust in social commerce.

As expected, trust in company-generated information is more important in boosting consumers' trust in social commerce contexts than trust in user-generated information is for the older generation (Gen.X: Busers $=0.275<$ Bcomp = 0.392), in comparison with the younger generation (Gen.Z: Busers $=0.492<$ Bcomp $=0.298$ ). According to previous studies, younger people are more influenced by content generated by other users (PricewaterhouseCoopers, 2016), perhaps because Z-ers are used to interact on social networks (Puro Marketing, 2015; Pieri and Diamantinir, 2010). However, contrary to the expected direction, it must be highlighted that the middle age group, Generation Y, showed a greater preference for trusting in content created by the company (Gen.Y: Busers $=0.167<\beta$ comp $=0.565$ ), to an even greater extent than $\mathrm{X}$-ers.

\section{Discussion and conclusions}

The aim of this study was to analyze which information type is more important in transferring trust in social commerce contexts, according to the different generational cohorts: content generated by users (user-generated information), or by the company (company-generated information). Following the idea that people are more likely to trust information that is shared by other consumers than by companies (Dabholkar and Sheng, 2012; Smith et al., 2005; Dellarocas et al., 2007), the study compared how trust in these two types of information is transferred to trust in social commerce. The empirical findings also suggest that trust in company-generated information is more important in boosting trust in social commerce contexts than trust in user-generated information is. After analyzing how trust in user- and company-generated information impact trust in social commerce in general, the moderating effect of the generational cohorts was tested.

Generational cohorts do not all act in the same manner (Meriac et al., 2010), since consumers' behavior and attitudes vary with age (San-Martín et al., 2015; PricewaterhouseCoopers, 2016). However, there are group similarities (Bilgihan, 2016; Parment, 2011; Parment, 2013). Thus, the role of age as a moderator variable was studied by considering Generations $\mathrm{X}, \mathrm{Y}$ and $\mathrm{Z}$ in order to determine how trust in social commerce is impacted for these generations by trust in user-generated versus company-generated information. Although several studies have analyzed consumers' 
behavior based on one generation, there is a gap in the literature about the differences among generations.

Based on the idea that generations develop similar attitudes that differ from those of other age groups (Meriac et al., 2010), it can be stated that the development of consumer trust in social commerce based on the type of information varies among generational cohorts. As a rule of thumb, older generations prefer company-generated information, while younger cohorts are more influenced by user-generated information. Therefore, the general belief asserting that people are more likely to trust information shared by other consumers over that from companies (Dabholkar and Sheng, 2012; Dellarocas et al., 2007; Smith et al., 2005) must take age into consideration.

The data suggest that the youngest generation (Z-ers) develops trust in social commerce mainly based on trust in user-generated information, whereas the oldest generation (X-ers) relies on trust in company-generated information. Generation $\mathrm{Z}$ does not know a world without the Internet (Puro Marketing, 2015), while Generation X has lived in both (American Marketing Association, 2016b) offline and online worlds. In the latter, information comes mainly from companies or mass media, whereas in online environments, information can be accessed via websites, such as social commerce environments where users can buy, share content, exchange opinions, get advice, etc. (Ickler et al., 2009; Kim et al., 2012; Zhou et al., 2013). According to the results of this study, while Generation $\mathrm{Z}$ considers trust in user-generated information as more important in boosting trust in social commerce, for Generation $\mathrm{X}$ trust in company-generated information is the most significant.

It is surprising that millennials, who have been the focus of several e-commerce studies, showed less trust in user-generated information in this study. This may be the result of concerns about paid and fake online reviews (Filieri, 2015). Nevertheless, it must be pointed out that Generation Y is currently considered to comprise millennials - i.e., those aged 25 to 34 years old-following the exclusion of Generation Z - those aged between 15 and 24 years old-who were previously also classified as millennials. Thus, Y-ers are grouped as the "medium age" generation and are characterized as expert Internet users (Palmer, 2009), which makes them more reflective when it comes to the credibility of the various kinds of information they find on the Internet. In a nutshell, according to the current classification of generational cohorts, we have to look beyond the former classification of millennials (which included everyone under 34 years old) in order to divide between Generation Z (the youngest) and Generation Y (medium age). Based on this understanding, in comparing between Z-ers and Y-ers, the empirical findings contribute to the assumption that the more experience a generation has with the Internet, the more important trust in company-generated information is when it comes to transferring this to trust in social commerce.

Moreover, it is believed that Generation $\mathrm{Y}$ has influenced the evolution of social media as an important source of product information and is influenced by online reviews (Mangold and Smith, 2012). However, the data here show that Generation Y considers company-generated information as the most important type, even more so than does Generation $\mathrm{X}$. The percentage of variance explained for each individual generational cohort model $\left(\mathrm{R}^{2}\right.$ of trust in social commerce for $\mathrm{Y}$-ers $=$ $43.5 \%$ and for X-ers $=35.8 \%$ ) shows that the model fits better for Generation Y. Thus, we think that there are other factors involved in trust development related to quality of the information beyond the website itself. Hence, the unexpected result of Y-ers transferring trust in social commerce mainly from trust in company-generated information could also be due to the influence of other factors on trust in social commerce, as well as other factors that are not related to the online information, such as previous experience or familiarity with the brand. For future research, it would be interesting to observe which other website elements or persons can affect trust, such as trust in the information generated by influencers, as well as offline factors such as trust in the offline store or trust in the company's salespersons.

\section{Implications for theory and practice}


This study opens new horizons for both marketers and researchers. Regarding business implications, the findings show that trust in company-generated information influences trust in social commerce a great deal, what can be considered an important advantage for the company, since this kind of information can be controlled and thus adapted to the target generation. Depending on the website target - that is, only one, or several generational cohorts - companies must balance both types of information. However, it has been shown that users transfer trust from their trust in different types of information across generations. For instance, for companies whose target is X-ers, it would be advisable for the website to provide sufficient social commerce tools (e.g., ratings and recommendation systems, discussion boards, etc.) to enable users to rely on usergenerated information; meanwhile, for companies whose target is Y-ers, websites must focus on providing high-quality and appropriate company-generated information. Likewise, companies that target different generations through the same website should create a balance of both types of information. Hence, apart from paying attention to the management of user-generated content, websites must manage the content controlled and created by the company (which is also the easier information type to control). Nevertheless, consistent with the idea of the salience of user-generated content (Mangold and Smith, 2012), websites should define their user target carefully. If a website is aimed toward Z-ers, user-generated information should be taken into account, whereas websites focused on X-ers need to take greater account of content generated by the company. The most challenging generational cohort seems to be Y-ers that, during ages, have been labeled as the millennial generation consisting of techie digital natives (Bilgihan, 2016), however they behave as if they were no so interested on the online user-generated information. Nevertheless, according to the empirical results, it seems that Y-ers are changing and are becoming less influenced by usergenerated content compared to previously (Mangold and Smith, 2012). This changing environment is a current concern for companies, since it indicates that Generation $\mathrm{Y}$ is a difficult cohort to understand. Nevertheless, under no circumstances should companies focus only on one source of information; they have to combine both kinds, while focusing on the one that is most relevant to their target generational cohort. Over time, the members of these generational cohorts will grow older and will also evolve as a group; thus, companies should track them and study how time and evolution affect the different generations' behavior. In the same line, other generational cohorts will appear. In fact, some media has started to discuss the "newcomer generation"-those who are currently under 15 years old - a cohort that has grown up surrounded by target advertising, influencers, ubiquity technology, smartphones, touchable screens and apps.

Thus, the theoretical contribution of this study is that both sources of information-user- and company-generated - generate trust, but in a different manner; we cannot consider users as a whole in social commerce contexts. It is necessary to segment generational cohorts and, depending on the target, try to boost the reliability of information from users or from the company. Trust in usergenerated information is not easy for the company to control, but website managers should be proactive when it comes to dealing with consumers' concerns, demands and questions.

\section{Limitations and future lines of research}

This study is not without limitations. First, it studied the reliability of information stemming from recommendations and referrals, ratings and reviews, and forums and virtual communities as a whole, as a second-order reflective factor. Participants were asked to report their experience with trust in user-generated information and were asked about how frank, reliable and trustworthy the information is. However, it would be interesting to discriminate between positive and negative content, since some studies have highlighted that the valence of the content can affect users differently, with negative online reviews even being more useful than positive ones (Casaló et al., 2015). Thus, future studies should consider how user-generated-information valence influences trust across generations. In the same line, some studies suggest that the level of involvement with the 
brand can also affect users' defensive behavior (Hassan and Casaló, 2016), what could also affect trust transferred.

Another line of research could focus on studying the role of influencers; that is, non-professional users who share their experiences and recommendations in blogs or social networks. Moreover, it is necessary to take into account information saturation-i.e., the amount of content on the website. It would be interesting to study how different information quantities affect users' perception of the information quality. Finally, it could be useful to explore the reason why Generation Y attitudes seem to be changing and whether this is also occurring within other generations.

\section{References}

Alam, S.S., Bakar, Z., Ismail, H.B. and Ahsan, M. (2008), "Young consumers online shopping: an empirical study", Journal of Internet Business, Vol. 5, No. 1, pp. 81-98.

Alshibly, H.H. (2014), "A free simulation experiment to examine the effects of social commerce website quality and customer psychological empowerment on customers' satisfaction", Journal of Business Studies Quarterly, Vol. 5, No. 4, pp. 21-40.

American Marketing Association (2016a), "Effective marketing to generation Z", available at: https://www.ama.org/events-training/Conferences/Pages/marketing-to-generation-Z.aspx (accessed 12 December 2016).

American Marketing Association (2016b), "Get to know Gen X: the small but mighty generation", available at: https://www.ama.org/resources/White\%20Papers/Pages/generation-X-the-smallbut-mighty-generation.aspx (accessed 5 March 2016).

Bagozzi, R.P. and Yi, Y. (1988), "On the evaluation of structural equation models", Journal of the Academy of Marketing Science, Vol. 16, No. 1, pp. 74-94.

Baron, R.M. and Kenny, D.A. (1986), "The moderator-mediator variable distinction in social psychological research: conceptual, strategic, and statistical considerations", Journal of Personality and Social Psychology, Vol. 51, No. 6, pp. 1173-1182.

Beldad, A., De Jong, M. and Steehouder, M. (2010), "How shall I trust the faceless and the intangible? A literature review on the antecedents of online trust", Computers in Human Behavior, Vol. 26, No. 5, pp. 857-869.

Bilgihan, A. (2016), "Gen Y customer loyalty in online shopping: an integrated model of trust, user experience and branding", Computers in Human Behavior, Vol. 61, pp. 103-113.

Bilgihan, A., Okumus, F. and Cobanoglu, C. (2013), "Generation Y travelers' commitment to online social network websites", Tourism Management, Vol. 35, pp. 13-22.

Blasco-Arcas, L., Hernández-Ortega, B. and Jiménez-Martínez, J. (2014), "The online purchase as a context for co-creating experiences: drivers of and consequences for customer behavior", Internet Research, Vol. 24, No. 3, pp. 393-412.

Bock, G., Lee, J., Kuan, H. and Kim, J. (2012), "The progression of online trust in the multichannel retailer context and the role of product uncertainty", Decision Support Systems, Vol. 53, No. 1, pp. 97-107.

Brosdahl, D.J. and Carpenter, J.M. (2011), "Shopping orientations of US males: a generational cohort comparison", Journal of Retailing and Consumer Services, Vol. 18, No. 6, pp. 548-554.

Campbell, D.T. and Fiske, D.W. (1959), "Convergent and discriminant validation by the multitraitmultimethod matrix", Psychological Bulletin, Vol. 56, No. 2, pp. 81-105.

Casaló, L.V., Flavián, C., Guinalíu, M. and Ekinci, Y. (2015), "Avoiding the dark side of positive online consumer reviews: enhancing reviews' usefulness for high risk-averse travelers", Journal of Business Research, Vol. 68, No. 9, pp. 1829-1835.

Cao, X., Yu, L., Liu, Z., Gong, M. and Adeel, L. (2018), "Understanding mobile payment users' continuance intention: a trust transfer perspective", Internet Research, Vol. 28 No. 2, pp. 456476.

Constantinides, E. (2014), "Foundations of social media marketing", Procedia-Social and Behavioral Sciences, Vol. 148, pp. 40-57. 
Chen, J.V., Yen, D.C., Pornpriphet, W. and Widjaja, A.E. (2015), "E-commerce web site loyalty: a cross cultural comparison", Information Systems Frontiers, Vol. 17, No. 6, pp. 1283-1299.

Chen, J. and Shen, X.L. (2015), "Consumers' decisions in social commerce context: an empirical investigation", Decision Support Systems, Vol. 79, pp. 55-64.

Chin, W.W. (2000), "FAQ-Partial Least Squares and PLSGraph", available at: http://discnt.cba.uh.edu/chin/plsfaq.htm (accessed 20 January 2016).

Dabholkar, P.A. and Sheng, X. (2012), "Consumer participation in using online recommendation agents: effects on satisfaction, trust, and purchase intentions", The Service Industries Journal, Vol. 32, No. 9, pp. 1433-1449.

Dellarocas, C., Zhang, X.M. and Awad, N.F. (2007), "Exploring the value of online product reviews in forecasting sales: the case of motion pictures", Journal of Interactive Marketing, Vol. 21, No. 4, pp. 23-45.

Farivar, S., Turel, O. and Yuan, Y. (2017), "A trust-risk perspective on social commerce use: an examination of the biasing role of habit", Internet Research, Vol. 27, No. 3, pp. 586-607.

Filieri, R. (2015), "Why do travelers trust TripAdvisor? Antecedents of trust towards consumergenerated media and its influence on recommendation adoption and word of mouth", Tourism Management, Vol. 51, pp. 174-185.

Fornell, C. and Larcker, D.F. (1981), "Evaluating structural equation models with unobservable variables and measurement error", Journal of Marketing Research, Vol. 18, No. 1, pp. 39-50.

Forrester (2016), "The data digest: the yin and yang of consumer decisions", available at: http://blogs.forrester.com/anjali_lai/16-04-21the data digest the yin and yang of consumer decisions?cm mmc=RSS- -MS- -1710- blog_6584 (accessed 26 April 2016).

Gan, C. and Wang, W. (2017), "The influence of perceived value on purchase intention in social commerce context", Internet Research, Vol. 27, No. 4, pp. 772-785.

Gefen, D. and Straub, D.W. (2003), "Managing user trust in B2C e-services", E-service Journal, Vol. 2, No. 2, pp. 7-24.

Grabner-Kräuter, S. and Kaluscha, E.A. (2003), "Empirical research in on-line trust: a review and critical assessment", International Journal of Human-Computer Studies, Vol. 58, No. 6, pp. 783-812.

Grange, C. and Benbasat, I. (2010), "Online social shopping: the functions and symbols of design artifacts", in IEEE Computer Society Press, Proceedings of the 43rd Hawaii International Conference on System Sciences, Kauai, HI,2010, R. Sprague (ed.), Washington, DC, pp. 1-10.

Hair Jr, J.F., Hult, G.T.M., Ringle, C. and Sarstedt, M. (2014), A Primer on Partial Least Squares Structural Equation Modeling (PLS-SEM), Thousand Oaks: Sage Publications, California, CA.

Hair, J., Anderson, R., Tatham, R. and Black, W. (1999), Multivariate Data Analysis, Prentice-Hall International, New Jersey, NJ.

Hair, J.F., William C.B., Barry J. B. and Rolph, E.A. (2010), Multivariate Data Analysis: A Global Perspective, 7th ed., Pearson, London, England.

Hajli, N. (2015), "Social commerce constructs and consumer's intention to buy", International Journal of Information Management, Vol. 35, No. 2, pp. 183-191.

Hajli, N., Lin, X., Featherman, M.S. and Wang, Y. (2014), "Social word of mouth: how trust develops in the market", International Journal of Market Research, Vol. 56, No. 5, pp. 673689.

Han, B. and Windsor, J. (2011), "User's willingness to pay on social network sites", Journal of Computer Information Systems, Vol. 51, No. 4, pp. 31-40.

Han, M. (2014), "How social network characteristics affect users' trust and purchase intention", International Journal of Business and Management, Vol. 9, No. 8, pp. 122.

Hassan, M. and Casaló, L.V. (2016), "Consumer devotion to a different height: how consumers are defending the brand within Facebook brand communities", Internet Research, Vol. 26, No. 4, pp. 963-981. 
Henseler, J., Ringle, C.M. and Sarstedt, M. (2015), "A new criterion for assessing discriminant validity in variance-based structural equation modeling", Journal of the Academy of Marketing Science, Vol. 43, No. 1, pp. 115-135.

Henseler, J., Ringle, C.M. and Sinkovics, R.R. (2009), "The use of partial least squares path modeling in international marketing", Advances in International Marketing, Vol. 20, No. 1, pp. 277-319.

Hernández, B., Jiménez-Martínez, J. and Martín, M.J. (2009), "Key website factors in e-business strategy", International Journal of Information Management, Vol. 29, No. 5, pp. 362-371.

Hill, W.W. and Beatty, S.E. (2011), "A model of adolescents' online consumer self-efficacy (OCSE)", Journal of Business Research, Vol. 64, No. 10, pp. 1025-1033.

Himmel, B. (2008), "Different strokes for different generations", Rental Product News, Vol. 30, No. 7, pp. 42-46.

Hodis, M.A., Sriramachandramurthy, R. and Sashittal, H.C. (2015), "Interact with me on my terms: a four segment Facebook engagement framework for marketers", Journal of Marketing Management, Vol. 31, No. 11-12, pp. 1255-1284.

Howe, N. and Strauss, W. (1992), Generations: the History of America's Future, 1584 to 2069, Harper Collins, New York, NY.

Hassanein, K. and Head, M. (2007), "Manipulating perceived social presence through the web interface and its impact on attitude towards online shopping", International Journal of HumanComputer Studies, Vol. 65, pp. 689-708.

Huang, Z. and Benyoucef, M. (2013), "From e-commerce to social commerce: a close look at design features", Electronic Commerce Research and Applications, Vol. 12, No. 4, pp. 246259.

Ickler, H., Schülke, S., Wilfling, S. and Baumöl, U. (2009), "New challenges in e-commerce: how social commerce influences the customer process", paper presented at the National Conference on Computing and Information Technology (NCCIT), 22 May, Songkhla, Thailand, available at: http://citeseerx.ist.psu.edu/viewdoc/download?doi=10.1.1.460.5449\&rep=rep1\&type=pdf (accessed 10 September 2016).

Inglehart, R. (1977), The Silent Revolution: Changing Values and Political Styles among Western Publics, Princeton University Press, New Jersey, NJ.

Jackson, V., Stoel, L. and Brantley, A. (2011), "Mall attributes and shopping value: differences by gender and generational cohort", Journal of Retailing and Consumer Services, Vol. 18, No. 1, pp. 1-9.

Jiao, Y., Gao, J. and Yang, J. (2015), "Social value and content value in social media: two ways to flow", Journal of Advanced Management Science, Vol. 3, No. 4, pp. 299-306.

Jung, L. (2014), "A study of affecting the purchasing intention of social commerce", International Journal of Software Engineering and Its Applications, Vol. 8, No. 5, pp. 73-84.

Kaiser, H.F. (1970), "A second generation little jiffy", Psychometrika, Vol. 35, No. 4, pp. 401-415.

Kaiser, H.F. (1974), "Little Jiffy, Mark IV", Educational and Psychological Measurement, Vol. 34, pp. 111-117.

Kantar Millward Brown (2016), "Media and digital predictions 2017", available at: http://www.millwardbrown.com/mb-global/our-thinking/insights-opinion/articles/digitalpredictions/2017/2017-digital-and-media-predictions (accessed 20 December 2016).

Keil, M., Tan, B.C., Wei, K., Saarinen, T., Tuunainen, V. and Wassenaar, A. (2000), "A crosscultural study on escalation of commitment behavior in software projects", MIS Quarterly, Vol. 24, No. 2, pp. 299-325.

Kim, C., Galliers, R.D., Shin, N., Ryoo, J. and Kim, J. (2012), "Factors influencing Internet shopping value and customer repurchase intention", Electronic Commerce Research and Applications, Vol. 11, No. 4, pp. 374-387.

Kim, D. (2013), "Under what conditions will social commerce business models survive?", Electronic Commerce Research and Applications, Vol. 12, No. 2, pp. 69-77. 
Kim, D. and Ammeter, A.P. (2008), "Examining shifts in online purchasing behavior: decoding the 'Net generation'", Academy of Information and Management Sciences, Vol. 12, No. 1, pp. 7-12.

Kim, D.J., Ferrin, D.L. and Rao, H.R. (2008), "A trust-based consumer decision-making model in electronic commerce: the role of trust, perceived risk, and their antecedents", Decision Support Systems, Vol. 44, No. 2, pp. 544-564.

Kim, S., Noh, M. and Lee, K. (2012), "Effects of antecedents of collectivism on consumers' intention to use social commerce", Journal of Applied Sciences, Vol. 12, No. 12, pp. 12651273.

Kim, S. and Park, H. (2013), "Effects of various characteristics of social commerce (s-commerce) on consumers' trust and trust performance", International Journal of Information Management, Vol. 33, No. 2, pp. 318-332.

Kuan, H. and Bock, G. (2007), "Trust transference in brick and click retailers: an investigation of the before-online-visit phase", Information \& Management, Vol. 44, No. 2, pp. 175-187.

Lester, D.H., Forman, A.M. and Loyd, D. (2006), "Internet shopping and buying behavior of college students", Services Marketing Quarterly, Vol. 27, No. 2, pp. 123-138.

Liang, T. and Turban, E. (2011), "Introduction to the special issue social commerce: a research framework for social commerce", International Journal of Electronic Commerce, Vol. 16, No. 2, pp. 5-14.

Liao, C., Palvia, P. and Lin, H.N. (2006), "The Roles of Habit and Web Site Quality in ECommerce", International Journal of Information Management, Vol. 26, No. 6, pp. 469-483

Lin, J.C. and Lu, H. (2000), "Towards an understanding of the behavioural intention to use a web site", International Journal of Information Management, Vol. 20, No. 3, pp. 197-208.

Linda, S. (2010), "Social commerce-e-commerce in social media context", World Academy of Science, Engineering and Technology, Vol. 72, pp. 39-44.

Lissitsa, S. and Kol, O. (2016), "Generation X vs. Generation Y-A decade of online shopping", Journal of Retailing and Consumer Services, Vol. 31, pp. 304-312.

Liu, Q.B., Karahanna, E. and Watson, R.T. (2011), "Unveiling user-generated content: designing websites to best present customer reviews", Business Horizons, Vol. 54, No. 3, pp. 231-240.

Lu, B. and Fan, W. and Zhou (2016), "Social Presence, trust, and social commerce purchase intention: an empirical research", Computers in Human Behavior, Vol. 56, pp. 225-237.

Mangold, W.G. and Smith, K.T. (2012), "Selling to millennials with online reviews", Business Horizons, Vol. 55, No. 2, pp. 141-153.

Meredith, G. and Schewe, C. (1994), "The power of cohorts", American Demographics, Vol. 16, No. 12, pp. 22-28.

Meriac, J.P., Woehr, D.J. and Banister, C. (2010), "Generational differences in work ethic: an examination of measurement equivalence across three cohorts", Journal of Business and Psychology, Vol. 25, No. 2, pp. 315-324.

$\mathrm{Ng}$, C.S. (2013), "Intention to purchase on social commerce websites across cultures: a crossregional study", Information \& Management, Vol. 50, No. 8, pp. 609-620.

Nunnally, J.C. (1978), Psychometric Theory, 2nd ed., McGraw-Hill, New York, NY.

Nunnally, J.C. and Bernstein, I. (1994), Psychometric Theory, 3rd ed., McGraw-Hill, New York, NY.

ONTSI (2014), "Informe anual la sociedad en red 2013, Observatorio Nacional de las Telecomunicaciones y de la Sociedad de la Información", available at: http://www.ontsi.red.es/ontsi/sites/default/files/informe_anual_la_sociedad_en_red_2013_ed._ 2014.pdf (accessed 10 February 2015).

Palmer, K. (2009), "Gen Y: influenced by parents and materialism", available at: http://money.usnews.com/money/blogs/alpha-consumer/2009/09/22/gen-y-influenced-byparents-and-materialism (accessed 24 April 2016). 
Parment, A. (2013), "Generation Y vs. Baby Boomers: shopping behavior, buyer involvement and implications for retailing", Journal of Retailing and Consumer Services, Vol. 20, No. 2, pp. 189-199.

Parment, A. (2011) Generation Y in Consumer and Labour Markets, Routledge, New York, NY.

Pavlou, P. and Gefen, D. (2004), "Building effective online marketplaces with institution-based trust", Information Systems Research, Vol. 15, No. 1, pp. 37-59.

Pentecost, R. and Andrews, L. (2010), "Fashion retailing and the bottom line: the effects of generational cohorts, gender, fashion fanship, attitudes and impulse buying on fashion expenditure", Journal of Retailing and Consumer Services, Vol. 17, No. 1, pp. 43-52.

Pieri, M. and Diamantinir, D. (2010), "Young people, elderly and ICT", Procedia-Social and Behavioral Sciences, Vol. 2, No. 2, pp. 2422-2426.

Prahalad, C.K. and Ramaswamy, V. (2004), "Co-creation experiences: the next practice in value creation", Journal of Interactive Marketing, Vol. 18, No. 3, pp. 5-14.

PricewaterhouseCoopers (2016), "Total retail global report 2016", available at: http://www.pwc.com/us/en/retail-consumer/publications/assets/Total-Retail-Global-Report.pdf (accessed 1 April 2016).

Puro Marketing (2015), "Olvidad a los millennials: 2015 es el año de la Generación Z", available at: http://www.puromarketing.com/88/23795/olvidad-millennials-ano-generacion.html (accessed 29 January 2016).

Ringle, C. M., Wende, S. and Becker, J. (2015), "SmartPLS 3, Boenningstedt: SmartPLS GmbH", available at: $h t t p: / / w w w . s m a r t p l s . c o m ~(a c c e s s e d 11$ November 2016).

San-Martín, S., Prodanova, J. and Jiménez, N. (2015), "The impact of age in the generation of satisfaction and WOM in mobile shopping", Journal of Retailing and Consumer Services, Vol. 23, pp. 1-8.

Sánchez-Franco, M.J. and Roldán, J.L. (2005), "Web acceptance and usage model: a comparison between goal-directed and experiential web users", Internet Research, Vol. 15, No. 1, pp. 2148.

Schewe, C.D., Meredith, G.E. and Noble, S.M. (2000), "Defining moments: segmenting by cohorts", Marketing Management, Vol. 9, No. 3, pp. 48-53.

See-To, E.W. and Ho, K.K. (2014), "Value co-creation and purchase intention in social network sites: the role of electronic word-of-mouth and trust: a theoretical analysis", Computers in Human Behavior, Vol. 31, pp. 182-189.

Sharma, S. and Crossler, R.E. (2014), "Disclosing too much? Situational factors affecting information disclosure in social commerce environment", Electronic Commerce Research and Applications, Vol. 13, No. 5, pp. 305-319.

Sharma, S., Durand, R.M. and Gur-Arie, O. (1981), "Identification and analysis of moderator variables", Journal of Marketing Research, Vol. 18, No. 3, pp. 291-300.

Shi, S. and Chow, W.S. (2015), "Trust development and transfer in social commerce: prior experience as moderator", Industrial Management \& Data Systems, Vol. 115, No. 7, pp. 11821203.

Wu, J.J., Chen, Y.H., Chien, S.H. and Wu, W.K. (2016), "Attachment relationship study of trust and trust transfer", Journal of Service Theory and Practice, Vol. 26, No. 5, pp. 681-695.

Smith, D., Menon, S. and Sivakumar, K. (2005), "Online peer and editorial recommendations, trust, and choice in virtual markets", Journal of Interactive Marketing, Vol. 19, No. 3, pp. 15-37.

Stewart, K.J. (2003), "Trust transfer on the world wide web", Organization Science, Vol. 14, No. 1, pp. 5-17.

Straub, D.W. (1989), "Validating instruments in MIS research", MIS Quarterly, Vol. 13, No. 2, pp. 147-169.

Yang, K., Li, X., Kim, H. and Kim, Y.H. (2015), "Social shopping website quality attributes increasing consumer participation, positive eWOM, and co-shopping: the reciprocating role of participation", Journal of Retailing and Consumer Services, Vol. 24, pp. 1-9. 
Yoon, H.S. and Occeña, L.G. (2015), "Influencing factors of trust in consumer-to-consumer electronic commerce with gender and age", International Journal of Information Management, Vol. 35, No. 3, pp. 352-363.

Yoon, S. (2002), "The antecedents and consequences of trust in online-purchase decisions", Journal of Interactive Marketing, Vol. 16, No. 2, pp. 47-63.

Zhang, H., Lu, Y., Gupta, S. and Zhao, L. (2014), "What motivates customers to participate in social commerce? The impact of technological environments and virtual customer experiences", Information \& Management, Vol. 51, No. 8, pp. 1017-1030.

Zhang, K.Z. and Benyoucef, M. (2016), "Consumer behavior in social commerce: a literature review", Decision Support Systems, Vol. 86, pp. 95-108.

Zhou, L., Zhang, P. and Zimmermann, H. (2013), "Social commerce research: an integrated view", Electronic Commerce Research and Applications, Vol. 12, No. 2, pp. 61-68. 